\title{
ANALISIS KENDALA PENERAPAN PROGRAM KURIKULUM 2013 PADA KELAS 2 SD NEGERI 1 JOMBOR
}

\author{
Nurma Dwi Lestari ${ }^{1}$, Muhammad Arief Budiman ${ }^{2}$, Eka Sari Setianingsih ${ }^{3}$ \\ Fakultas Ilmu Pendidikan, PGSD, Universitas PGRI Semarang \\ Email: nurmadwi197@gmail.com
}

\begin{abstract}
The purpose of this research was to describe the difficulty experience in the implementation of the 2013 curriculum in class II SD Negeri 1 Jombor in the learning process. This research is motivate by the learning process that takes place in Class II of SD N 1 Jombor by using the 2013 Curriculum is not running well, most students still cannot understand the learning material available in the given textbook. This research used a qualitative research method with a descriptive approach and by using questionaire and interview methods. After conducting the research, the results obtained were the readiness of the teacher in teaching using Curriculum 2013 which included the allocation of time in the implementation of learning, the delivery of learning and assessment materials. Besides the research experienced by students when implementing learning using Curriculum 2013 was the level of understanding of students towards learning materials that are different between one another.
\end{abstract}

Keywords: analysis, difficulty, curriculum 2013

\begin{abstract}
Abstrak
Tujuan dari penelitian ini adalah untuk mendeskripsikan kendala yang dialami dalam penerapan kurikulum 2013 di kelas II SD Negeri 1 Jombor pada proses pembelajaran. Penelitian ini dilatar belakangi oleh proses pembelajaran yang berlangsung di Kelas II SD N 1 Jombor dengan mengunakan Kurikulum 2013 kurang berjalan dengan baik, sebagian besar peserta didik masih belum bisa memahami materi pembelajaran yang ada pada buku teks yang diberikan. Penelitian ini menggunakan metode penelitain kualitatif dengan pendekatan deskriptif dan dengan menggunakan metode angket dan wawancara. Setelah dilaksanakan penelitian, hasil yang diperoleh adalah kesiapan guru dalam mengajar menggunakan Kurikulum 2013 yang meliputi pengalokasian waktu dalam pelaksanaan pembelajaran, penyampaian materi pembelajaran dan penilaian. Selain itu kendala yang dialami peserta didik saat pelaksanaan pembelajaran dengan menggunakan Kurikulum 2013 adalah tingkat pemahaman peserta didik terhadap materi pembelajaran yang berbeda antar satu dengan yang lain.
\end{abstract}

Kata Kunci: analisis, kendala, kurikulum 2013 


\section{PENDAHULUAN}

Pada era globalisasi dan semakin majunya perkembangan teknologi yang saat ini semakin meningkat, menuntut manusia untuk terus berinovatif dan memiliki kualitas yang tinggi. Kualitas manusia yang dibutuhkan oleh bangsa pada masa yang akan datang adalah kualitas manusia yang mampu bersaing dalam persaingan yang semakin ketat dalam berbagai bidang antara lain adalah bidang pendidikan.

Pendidikan merupakan suatu pilar ataupun pondasi bagi suatu negara untuk mengembangkan kemakmuran negara, negara dikatakan berhasil dalam memberantas kebodohan apabila angka putus sekolah rendah, berdasarkan Undang- Undang Republik Indonesia Nomor 20 Tahun 2003 tentang Sistem Pendidikan Nasional berikut ini menyatakan bahwa " Pendidikan adalah usaha sadar dan terencana untuk mewujudkan suasana belajar dan proses pembelajaran agar peserta didik secara aktif mengembangkan potensi dirinya untuk memiliki kekuatan spiritual keagamaan, pengendalian diri, keterampilan, keperibadian, kecerdasan, akhlak mulia, serta keterampilan yang diperlukan dirinya, masyarakat, bangsa dan negara".

Menurut Hamalik (2011:57) pembelajaran merupakan suatu kombinasi yang tersusun meliputi unsur-unsur manusiawi, material, fasilitas, perlengkapan dan prosedur yang saling mempengaruhi mencapai tujuan pembelajaran. Manusia terlibat dalam sistem pengajaran terdiri dari siswa, guru, dan tenaga lainnya.

Pada proses pelaksanaan pembelajaran, variabel yang penting adalah kurikulum. Kurikulum adalah seperangkat rencana dan peraturan mengenai isi dan bahan pelajaran, serta cara yang digunakan sebagai pedoman penyelenggaraan kegiatan belajar mengajar (Undang- undang No. 2 Tahun 1989). Kurikulum di Indonesia telah mengalami banyak sekali pergantian kurikulum dimulai dari Rencana Pelajaran 1947, Rencana Pelajaran Terurai 1952, Kurikulum 1968, Kurikulum 1975, Kurikulum 1984, Kurikulum 1994, Kurikulum Berbasis Kompetensi (KBK), Kurikulum Tingkat satuan 
Pendidikan (KTSP), dan Kurikulum 2013

Menurut Zais (Widyastono, 2014:2) menjelaskan bahwa kurikulum bukan hanya merupakan rencana tertulis bagi pengajar, melainkan sesuatu yang fungsional, yang memberi pedoman dan mengatur lingkunga dan kegiatan yang berlangsung di dalam kelas.

Pergantian kurikulum dilakukan karena kurikulum harus disesuaikan dengan tuntutan dan perkembangan zaman. Setiap perubahan kurikulum memiliki tujuan tertentu guna meningkatkan kualitas pendidikan yang ada di Indonesia, akan tetapi setiap perubahan tentunya akan menimbulkan kendala dalam proses penerapannya. Kurikulum 2013 merupakan kurikulum yang baru digunakan, maka banyak kalangan pendidikan khususnya guru yang belum mengetahui mengnai Kurikulum 2013 (Mulyasa, 2013: 29$60)$.

Menurut Akbar, dkk (2017:17) Kurikulum 2013 merupakan kurikulum yang sifatnya tematik, dalam proses pembelajaran lebih menekankan pada pembentukan karakter siswa. Pembelajaran yang mengintegrasikan berbagai kompetensi dan berbagai mata pelajaran ke dalam tema dengan proses pembelajaran yang bermakna disesuaikan dengan perkembangan siswa.

Hidayat

(2013:158-159) implementasi kurikulum adalah bagaimana membelajarkan pesanpesan kepada peserta didik untuk menghasilkan lulusan yang memiliki seperangkat kompetensi mereka sesuai dengan karakteristik dan kemampuan masing - masing. Pada awal diimplementasikannya Kurikulum 2013 telah menuai banyak respon baik positif maupun negatif. Penerapan Kurikulum 2013 dinilai terlalu terburu-buru dan kurang memperhatikan kesiapan dari setiap satuan pendidikan dan juga guru. Padahal Kurikulum 2013 ini mencakup banyak perubahan, baik dalam hal implementasi maupun evaluasi pembelajarannya. Dari berbagai sumber di media masa penerapan Kurikulum 2013 masih menuai banyak sekali kendala dalam 
pelaksanaannya, singkatnya masa sosialisasi guru mengenai Kurikulum 2013 yang hanya dilakukan selama 6 bulan dengan jumlah sekitar 3 juta guru dengan kemampuan yang beragam dirasa kurang untuk membekali guru dalam penerapan program Kurikulum 2013. Materi yang termuat dalam Kurikulum 2013 sangatlah berbeda dengan Kurikulum sebelumnya sehingga dalam pengajaran guru belum maksimal.

Implementasi Kurikulum 2013 menuntut guru untuk mengorganisasikan pembelajaran secara efektif. Sedikitnya terdapat lima hal yang perlu diperhatikan berkaitan dengan implementasi Kurikulum 2013 yaitu pelaksanaan pembelajaran, pengadaan dan pembinaan tenaga ahli, pendayagunaan lingkungan dan sumber daya masyarakat, serta pengembangan dan penataan kebijakan Mulyasa (2013:104). Proses pembelajaran merupakan hal yang paling penting dan mendasar dalam pengimplementasian kurikulum.

Proses pembelajaran dalam penerapan Kurikulum 2013 yang berbasis karakter dan kompetensi hendaknya dilaksanakan berdasarkan kebutuhan dan karakteristik peserta didik. Oleh karena itu, implementasi Kurikulum 2013 dilakukan dengan pendekatan tematik integratif.

Melalui

Implementasi

Kurikulum 2013 sering kali menemukan berbagai kendala dalam pelaksanaannya, diantaranya dalam proses pembelajaran. Penerapan pembelajaran saintifik dan keaktifan peserta didik masih kurang membuat penerapan program Kurikulum 2013 yang memiliki tujuan membuat proses pembelajaran yang aktif dan inovatif menjadi sangat sulit terwujud. Permasalahan tersebut didukung dengan hasil observasi pendahulauan yang dilakukan peneliti pada Kelas II SD N 1 Jombor diperoleh bahwa data sebagai berikut: 
Volume 2 Nomor 2, Edisi Desember 2019

Prodi PGSD Universitas Slamet Riyadi

ISSN 2620-6560 (print) ISSN 2620-746X (online)

Tabel 1. Hasil Observasi

\begin{tabular}{rlcc}
\hline No & Indikator & Nomer Pernyataan & Jumlah Skor \\
\hline 1. & $\begin{array}{l}\text { Perangkat } \\
\text { Pembelajaran }\end{array}$ & $1,8,12,14$ & 11 \\
\hline 2. & $\begin{array}{l}\text { Proses } \\
\text { Pembelajaran }\end{array}$ & $2,3,4,5,6,7,9$ & 14 \\
3. & $\begin{array}{l}\text { Pelibatan } \\
\text { Peserta Didik } \\
\text { dalam } \\
\text { Pembelajaran }\end{array}$ & $10,11,13,15$ & \\
\hline & Jumlah & 31 \\
\hline
\end{tabular}

Diperoleh hasil sejumlah $41 \%$, selain itu dalam penerapan. Kurikulum 2013 di Kelas II SD Negeri 1 Jombor diperoleh bahwa: (1) proses pembelajaran yang berlangsung di Kelas II SD $\mathrm{N} \quad 1$ Jombor dengan mengunakan Kurikulum 2013 kurang berjalan dengan baik, (2) sebagian besar peserta didik masih belum bisa memahami materi pembelajaran yang ada pada buku teks yang diberikan, sehingga menghambat guru dalam penyampaian materi pembelajaran yang guru sampaikan. Rumusan masalah ini yaitu bagaimana kendala penerapan program kurikulum 2013 padpada proses pelaksanaan pembelajaran di kelas II SD Negeri 1 Jombor.

\section{METODE PENELITIAN}

Penelitian ini merupakan peneltian deskriptif yang mendeskipsikan secara luas mengenai kendala penerapan program Kurikulum 2013 di kelas II pada proses pembelajaran. Subjek penelitian ini terdiri atas 21 orang siswa, guru kelas 2 dan kepala sekolah SD Negeri 1 Jombor.

Teknik pengumpulan data dalam penelitian ini adalah dengan menggunakan metode angket dan wawancara. Instrumen penelitian berupa pedoman angket dan wawancara. Validasi data yang digunakan dalam penelitian ini untuk menguji kredibilitas adalah dengan triangulasi. Analisis data dilakukan melalui tiga jalur yaitu: data reduction yaitu proses pemilihan dan pemusata data terhadap data yang 
diperoleh di lapangan. Data display yaitu penyajian informasi yang telah disusun yang kemungkinan memberikan penarikan kesimpulan, dan Conclusion drawing atau verification yaitu merupakan penarikan kesimpulan, yang mana peneliti menemukan temuan baru yang sebelumnya belum pernah ada.

Temuan dapat berupa deskripsi atau gambaran suatu obyek yang sebelumnya masih remang-remang atau gelap sehingga setelah diteliti menjadi jelas.

\section{HASIL DAN PEMBAHASAN}

Data yang diperoleh dari hasil angket siswa, angket guru dan wawancara menunjukkan bahwa kendala penerapan program Kurikulum 2013 di kelas II SD Negeri 1 Jombor dalam proses pelaksanaan pembelajaran adalah sebagai berikut:

Berdasarkan hasil angket yang diberikan pada 21 orang responden, dapat digambarkan bahwa responden yaitu 21 orang siswa kelas II SD Negeri 1 Jombor masih menemui kendala dalam pelaksanaan Kurikulum 2013. Hal tersebut ditunjukkan pernyataan angket pada poin ke 1 "Saya mengetahui bahwa saat ini berlangsung pembelajaran dengan Kurikulum 2103” poin ke 3 "Pada saat mengajar, guru selalu menggunakan media pembelajaran atau alat peraga", poin ke 6 "Materi pembelajaran pada buku siswa sangat mudah dipahami", poin ke 8 "Saya mengalami kesulitan saat memahami materi pembelajaran". Dari ketempat poin tersebut persentase responden menjawab tidak setuju lebih banyak daripada menjawab setuju, netral maupun sangat tidak setuju. Presentase poin ke 1 menjawab tidak setuju adalah $38 \%$, poin ke 3 adalah $52 \%$, poin ke 6 adalah $38 \%$, poin ke 8 adalah $76 \%$.

Hasil angket yang diberikan pada guru kelas II SD Negeri 1 Jombor masih menemui kendala dalam menerapkan program Kurikulum 2013. Hal tersebut ditunjukkan pada pernyataan angket pada poin ke 5 "Kurikulum 2013 lebih terarah dari kurikulum sebelumnya", poin ke 6 "Kurikulum 2013 menjadikan siswa lebih mandiri", poin ke 8 "Beban guru lebih ringan ketika menggunakan 
Kurikulum 2013 dibandingkan ketika menggunakan KTSP", poin ke 9 "Kurikulum 2013 lebih baik daripada kurikulum sebelumnya”. Dari keempat poin tersebut 3 poin responden menjawab sangat tidak setuju, hal ini menunjukkan bahwa diterapkannya program Kurikulum 2013 bahwa guru kelas II di SD Negeri 1 Jombor belum memiliki kenyamanan saat melaksanakan pembelajaran dengan menggunakan Kurikulum 2013, sedangkan pada poin ke 6 responden menjawab netral yang berarti pada pelaksanaan kurikulum 2013 di kelas II masih harus dituntun oleh guru dalam pelaksanaan pembelajarannya.

Hasil wawancara yang diberikan pada Kepala Sekolah, dapat digambarkan bahwa kendala penerapan program Kurikulum 2013 yang dialami oleh guru adalah dalam hal kesiapan guru dalam mengajar, pemaahaman materi pembelajaran oleh siswa, dan penilaian. Responden yaitu Kepala Sekolah sudah mengetahui dengan jelas kendala penerapan program kurikulum 2013. Hal itu ditunjukkan pada petanyaan poin keenam "Menurut Bapak/Ibu apa saja kendala dalam penerapan program Kurikulum 2013 di SD N 1 Jombor?" responden dengan jelas mengatakan bahwa kendala dalam penerapan kurikulum 2013 lebih pada penilaian dan juga materi pembelajaran. Guru - guru masih mengalami kesuliitan dengan sistem penilaian yang setiap pembelajaran memuat banyak sekali aspek yang dinilai yang tentunya menyulitkan bagi guru. Selain itu materi pembelajaran sangat sedikit sehingga pendalaman materi bagi siswa kurang.

Berdasarkan hasi angket dan hasil wawancara diatas, dapat diketahui bahwa kendala penerapan program Kurikulum 2013 di kelas II SD Negeri 1 Jombor dalam proses pelaksanaan pembelajaran adalah kesiapan guru dalam mengajar menggunakan Kurikulum 2013 yang meliputi pengalokasian waktu dalam pelaksanaan pembelajaran, penyampaian materi pembelajaran dan penilaian. Manajemen waktu saat pembelajaran juga menjadi salah satu kendala dalam pelaksanaan 


\section{Jurnal Sinektik}

Volume 2 Nomor 2, Edisi Desember 2019

Prodi PGSD Universitas Slamet Riyadi

ISSN 2620-6560 (print) ISSN 2620-746X (online)

pembelajaran dengan menggunakan Kurikulum 2013 hal ini disampaikan oleh guru bahwa terkadang materi dalam satu pembelajaran tidak selesai dalam waktu satu hari sehingga menghambat pembelajaran berikutnya. Dalam melakukan penilaian guru juga masih belum menguasai sistem penilaian pada Kurikulum 2013 yang mengacu pada beberapa aspek kognitif, afektif, dan psikomotorik. Dan kendala yang dialami siswa saat pelaksanaan pembelajaran dengan menggunakan Kurikulum 2013 adalah kurangnya pemahaman siswa mengenai materi pembelajaran

\section{SIMPULAN}

Berdasarkan hasil penelitian dan pembahasan yang telah diuraikan, dapat disimpulkan bahwa terdapat kendala dalam penerapan program Kurikulum 2013 pada proses pembelajaran, kendala yang dialami saat proses pembelajaran berlangsung adalah kesiapan guru dalam mengajar menggunakan Kurikulum 2013 yang meliputi pengalokasian waktu dalam pelaksanaan pembelajaran, model pembelajaran dan penilaian. Selain itu kendala yang dialami peserta didik saat pelaksanaan pembelajaran dengan menggunakan Kurikulum 2013 adalah tingkat pemahaman peserta didik terhadap materi pembelajaran yang berbeda antar satu dengan yang lain.

Setelah dilakukan penelitian, peneliti memberikan saran bagi guru, guru harus bisa menyesuaikan diri dengan perubahan kurikulum yang terjadi agar dapat menerapkan pembelajarn yang kreatif dan menarik sehingga pembelajaran dengan kurikulum yang baru dapat berjalan dengan baik. Bagi Fakultas dan Jurusan dengan adanya penelitian ini diharapkan dapat menciptakan guru atau calon pendidik yang berkompeten agar dapat memajukan kualitas pendidikan di Indonesia. Bagi Peneliti, terkait dengan hasil penelitian yang ditemukan oleh peneliti, peneliti yang merupakan calon guru harus mampu mengembangkan potensi dirinya agar menjadi guru yang kreatif, inovatif dan mampu memajukan kualitas pendidikan di Indonesia. Bagi Pemerintah, sebaiknya pemerintah harus lebih mengkaji penerapan 
Volume 2 Nomor 2, Edisi Desember 2019

Prodi PGSD Universitas Slamet Riyadi

ISSN 2620-6560 (print) ISSN 2620-746X (online)

kurikulum 2013 dengan melibatkan

guru dalam perencanaan program

kurikulum karena guru merupakan

kunci sukses pengemabangan

kurikulum.

\section{DAFTAR PUSTAKA}

Akbar, dkk. 2016. Implementassi Pembelajaran Tematik di Sekolah Dasar. Bandung: PT Remaja Rosdakarya Offset.

Hamalik, Oemar. 2011. Kurikulum dan Pembelajaran. Jakarta: PT Bumi Aksara.

Hidayat, Sholeh. 2013. Pengembangan Kurikulum Baru. Bandung: PT Remaja Rosdakarya Offset.

Mulyasa, E. 2013. Pengembangan dan Implementasi Kurikulum 2013. Bandung: PT Remaja Rosdakarya Offset.

Undang-undang Republik Indonesia Nomor 20 Tahun 2003 tentang Sistem Pendidikan Nasional. 2003. Jakarta: Kemendikbud.

Widyastono, Herry. 2014.

Pengembangan Kurikulum di Era Otonomi Daerah (dari Kurikulum 2004, 2006, ke Kurikulum 2013). Jakarta: PT Bumi Aksara. 